\title{
Спадкова та набута гемофілія A: сучасні підходи до лікування з клінічними прикладами
}

\author{
І.П. Цимбалюк-Волошин', О.Ю. Кучкова² \\ 'Західноукраїнський спеціалізований дитячий медичний центр, Львів, Україна \\ ²Обласний центр онкології, Харків, Україна
}

\begin{abstract}
Анотація. Класична гемофілія - X-зчеплене захворювання системи гемостазу, що характеризується зниженням або порушенням синтезу факторів згортання крові. За уявленням більшості лікарів, гемофілія $\epsilon$ спадковою патологією, але в клінічній практиці, окрім спадкової форми, відмічається набута гемофілія, яка належить до вкрай рідкісної патології, в основі якої лежить продукція аутоантитіл, що інактивують власні фактори згортання крові. У статті представлений огляд літератури щодо ключових аспектів менеджменту пацієнтів із гемофілією, фокусуючи увагу на проблемі набутої гемофілії А, а також наведені власні клінічні спостереження успішного лікування пацієнтів з інгібіторами до факторів згортання крові.
\end{abstract}

Ключові слова: гемофілія, гемостазіопатії, гемостаз, набута гемофілія А, шунтуючі препарати, фактор згортання крові, гемартроз.

\section{Набуті та спадкові гемостазіопатії}

Система гемостазу людини - багатокомпонентний і надзвичайно складний механізм, що являє собою групу біологічних реакцій, спрямованих на підтримку крові у рідкому стані або мінімізацію її втрати у разі пошкодження судин. Гемостазіопатії захворювання системи гемостазу, що зумовлені спадковими або набутими порушеннями компонентів системи згортання крові, в результаті чого порушуються ії основні функції, призводячи до таких тяжких ускладнень, як неконтрольовані кровотечі. Причиною підвищеної кровоточивості може бути ураження одного або декількох компонентів системи гемостазу, які прийнято поділяти на тромботичний, геморагічний та тромбогеморагічний синдром. При цьому важливо враховувати, що кожен із синдромів розподіляється на спадкові й набуті порушення гемостазу [1].

Зі спадкових порушень гемостазу найчастіше в терапевтичній практиці відмічають гемофілію - X-зчеплене захворювання системи гемостазу, що характеризується зниженням або порушенням синтезу факторів згортання крові: VIII (FVIII) при гемофілії типу A, IX (FIX) - В. Гемофілія наслідується за рецесивним типом спадковості, пов'язаним зі статтю. Ген, який відповідає за синтез FVIII та FIX, розміщений в X-хромосомі, внаслідок чого на гемофілію хворіють виключно чоловіки. За сучасними даними, гемофілія А - найпоширеніша та найтяжча форма спадкових коагулопатій, яка, окрім того, що належить до складних медичних проблем, також чинить значний вплив на соціальний аспект, оскільки призводить до ранньої втрати працездатності та інвалідизації хворих, переважно ще у дитячому віці. Відповідно до статистичних даних за 2017 p. в Україні кількість хворих на спадкові коагулопатії становила $>2$ тис. осіб із діагнозом «гемофілія», з яких 667 - діти. При цьому за поширенням Україна значно відрізняється від інших країн Європи, що пов'язано з відсутністю централізованого обліку кількості пацієнтів із діагнозом «гемофілія» та недостатньо ефективною діагностикою захворювання. Клінічна картина при спадковій гемофілії А супроводжується спонтанними тривалими кровотечами у м'язи та суглоби, при цьому тяжкість клінічного перебігу залежить від ступеня недостатності коагуляційної активності фактора згортання крові (рис. 1).

За уявленням більшості лікарів, гемофілія $\epsilon$ спадковою патологією. Однак в клінічній практиці, окрім спадкової форми, відмічається набута гемофілія - спонтанне аутоімунне захворювання - імунокоагулопатія, патогенез якої пов'язаний із синтезом специфічних аутоантитіл до одного з власних факторів крові, найчастіше до FVIII згортання крові - набута гемофілія А (НГА) [2]. НГА виявляєТься набагато рідше, ніж спадкова гемофілія A; статистичні дані свідчать, що її поширеність становить 1,2-1,48 випадка на 1 млн населення на рік. Важливо також відмі- тити, що істинна поширеність захворювання може бути вищою, оскільки в ряді випадків, особливо у пацієнтів літнього віку, НГА часто не діагностується, що пов'язано з установкою клініцистів на спадковий характер гемофілії.

Дані літератури повідомляють, що захворюваність на НГА, на відміну від спадкової гемофілії, підвищується з віком, зазвичай діагностується на 7-му десятку років життя, тоді як серед дітей їі випадки $\epsilon$ казуїстичними, а їі частота практично однакова серед чоловіків і жінок. Приблизно в 50\% випадків НГА виникає на тлі різних інтеркурентних захворювань і станів [3]. Найчастіше їі розвиток асоціюється $з$ такими станами, як гепатит, аутоімунні стани, захворюваннями шкіри та легень. Іноді НГА може бути першою ознакою онкологічного або системного захворювання, тому необхідно проводити ретельне обстеження пацієнтів. У 10\% випадків аутоантитіла до FVIII виникають наприкінці вагітності або в післяпологовий період [4]. При цьому вищому ризику піддаються жінки з 1-ю вагітністю. Патогенез розвитку післяпологової НГА не визначений, однак припускають, що пусковим моментом синтезу аутоантитіл у період вагітності $\epsilon$ сенсибілізація жінки фетальним FVIII [5].

\section{Утворення інгібіторів як ключова проблема менеджменту \\ пацієнтів із гемофілією}

Основний принцип лікування хворих на гемофілію - адекватна замісна гемостатична терапія концентратами факторів згортан-

\section{Рисунок 1 Гемостаз при гемофілії}

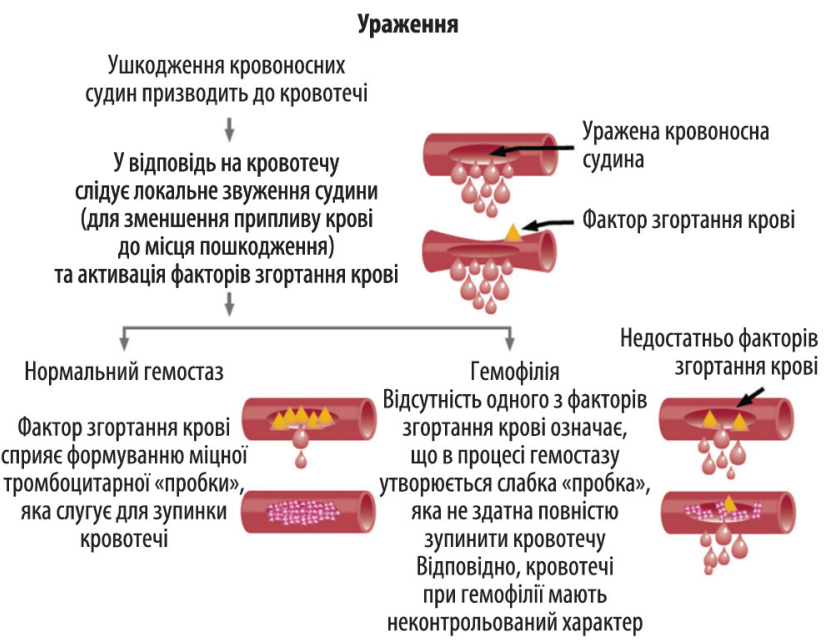


ня крові - факторна терапія. Однак незважаючи на суттєві досягнення у галузі гематології, і досі залишається проблемним питання розвитку ускладнень, пов'язаних із лікуванням [6]. Так, факторна терапія супроводжується ризиком розвитку інгібіторної форми гемофілії (ІФГ) - найсерйознішого ускладнення замісної терапії гемофілії, що характеризується утворенням інгібіторного антитіла до FVIII або FIX, яке не дозволяє проводити адекватну факторну терапію. Клінічно розвиток ІФГ проявляється зниженням ефективності замісної факторної терапії, зменшуючи активність або повністю нейтралізуючи введені концентрати факторів, що значно ускладнює тяжкість клінічного перебігу гемофілії, кровотечі набувають неконтрольованого характеру та наявна ймовірність раннього розвитку прогресуючої артропатії разом з більш високими витратами на лікування [7].

Частота розвитку ІФГ відображає тяжкість молекулярної вади: інгібітори до FVIII розвиваються у 20-35\% пацієнтів з тяжкою гемофілією А та у 3-13\% пацієнтів з легким/середньої тяжкості захворюванням. Розвиток ІФГ вже багато років викликає занепокоєння та значний інтерес наукової спільноти, оскільки це значно впливає на тяжкість перебігу гемофілії та знижує якість життя пацієнтів. За останні два десятиліття розуміння патофізіології утворення інгібіторів до факторів згортання крові значно покращилося. На сучасному етапі відомо, що цей процес $\epsilon$ багатокомпонентним і включає взаємодію різних клітин, включно з цитокінами та іншими клітинами імунної регуляції. За структурою інгібітор являє собою поліклональне високоафінне IgG-антитіло, яке спрямоване проти білка-фактора, специфічно нейтралізує його прокоагулянтну активність, що призводить до порушення процесів гемостазу, а також стимулює додаткове продукування антитіл [8].

Дані літератури свідчать, що розвиток інгібіторів до факторів згортання крові, імовірно, залежить від певних чинників, включно з сімейним анамнезом ІФГ, наявністю серйозних вад гена фактора згортання крові, етнічною приналежністю хворого (африканський родовід) та раннім інтенсивним лікуванням високими дозами концентратів фактора згортання крові (особливо першими 50 дозами) (рис. 2).

Для розвитку ІФГ має значення наявність декількох складових:

- генетична схильність: тип мутації, особливості HLA-генотипу, поліморфізм генів цитокінів та імунорегуляторних молекул;

- фенотипові особливості пацієнта: вік першої інфузії фактора, імунологічні порушення (імунізація, запалення, травма, операція);

- лікування (тип концентрату фактора FVIII або FIX, вид лікування) [9].

Рисунок 2 Фактори, пов'язані з розвитком ІФГ

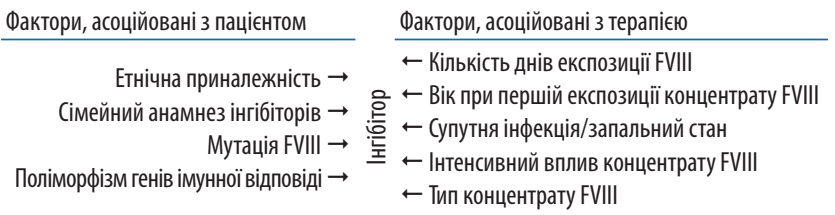

На частоту розвитку інгібіторів до факторів згортання крові також може впливати обраний спосіб лікування гемофілії. Так, дані літератури свідчать, що профілактичне лікування асоціюється з нижчим ризиком розвитку інгібіторів порівняно з лікуванням «за вимогою». Це твердження ґрунтується на гіпотезі про те, що загальний ризик розвитку інгібіторів пов'язаний з рівнем сигналів, отриманих імунною системою. Відповідно до цього можна стверджувати, що лікування «за вимогою» може призвести до частішого розвитку інгібіторів порівняно із профілактичним лікуванням. Результати дослідження W. Kreuz та співавторів (2005) підтвердили ці висновки та продемонстрували, що з 183 пацієнтів із гемофілією у $10 \%$ пацієнтів групи, учасники якої отримували профілактичне лікування, розвивалися інгібітори до факторів згортання крові порівняно 3 45\% пацієнтів групи лікування «за вимогою» [11].

Виділяють два типи інгібіторів до факторів згортання крові:

- алоантитіла (1-й тип): утворюються у відповідь на замісну факторну терапію при спадковій гемофілії. Ці антитіла інак- тивують FVIII з лінійною швидкістю, пов'язаною з їх концентрацією, і можуть повністю пригнічувати активність FVIII при високих концентраціях;

- аутоантитіла (2-й тип): утворюються раптово і наявні при НГА.

Ці антитіла мають нелінійний інгібуючий профіль, розвиваються раптово і частково пригнічують FVIII [10].

Аутоантитіла при НГА за структурою являють собою поєднання поліклональних імуноглобулінів класів G1, G2 та G4, які блокують ділянки A2, A3 та C2 доменів фактора згортання, що перешкоджає активації FVIII за рахунок блокування доменів в зонах впливу FIXa, FX і FB, таким чином виключаючи його з гемостазу. Ще однією важливою відмінністю між ІФГ та НГА $€$ те, що при спадковій гемофілії алоантитіла утворюються у дитячому віці, тоді як аутоантитіла при НГА відмічаються в осіб старшої вікової групи (>60 років), які раніше не мали порушень гемостазу (табл. 1).

Таблиця 1 Характерні відмінності між класичною гемофілією та НГА Порівняння особливостей перебігу НГА та спадкової гемофілії

\begin{tabular}{ll}
\hline \multicolumn{1}{c}{ нгА } & \multicolumn{1}{c}{ Спадкова гемофілія A } \\
\hline Більш характерна для осіб літнього віку & Більш характерна для дітей \\
\hline Жінки та чоловіки уражаються однаково & Уражаються переважно чоловіки \\
\hline Гемартрози виникають рідко & Характерні гемартрози \\
\hline Відсутнє співвідношення між титром & Алоантитіла інактивують FVIII у прямій \\
інгібітора, залишковою активністю FVIII & пропорції з їх концентрацією \\
і тяжкістю кровотеч &
\end{tabular}

Підвищений ризик смертності Відсутній безпосередній вплив на смертність

Відповідно до сучасних рекомендацій першочерговим моментом при менеджменті пацієнтів з ІФГ $є$ виявлення інгібітора до факторів згортання крові. Для цього використовують специфічний тест Бетезда чи його модифікацію Неймегена, який вимірює активність інгібіторів, виявлених у плазмі крові, та виражається в одиницях Бетезда (БО/мл) або титрі Бетезда. За 1 одиницю інгібітора (БО) приймають таку кількість, яка інактивує 50\% доданого FVIII або FIX в 1 мл плазми крові. Для верифікації інгібітора необхідне його повторне визначення з інтервалом в 1 тиж, позитивним вважають результат >0,6 БО. Відповідно до титру інгібітора пацієнтів з ІФГ прийнято розділяти на пацієнтів із:

- низьким титром/низькореагуючим - 0,6-<5 (БО/мл);

- високим/високореагуючим титром інгібітора - $\geq 5$ (БО/мл).

Титр інгібітора визначається за ступенем відповіді на стимуляцію імунної системи пацієнта повторними введеннями факторів згортання. Наприклад, якщо імунна система дає повільну та слабку відповідь на введення фактора, титр визначається як низький, а тип інгібітора - низькореагуючий. Якщо наявне швидке підвищення титру інгібітора після введення препарату, а кількість інгібітора протидіє фактору згортання, такий випадок визначається як високий/високореагуючий титр. Без подальших введень фактора цей титр може потім знизитися, проте цей процес може тривати багато місяців [12].

\section{Клінічні прояви спадкової та набутої гемофілії}

Гемофілія характеризується гематомним типом кровоточивості, відповідно, основним їі клінічним проявом $\epsilon$ кровотечі та крововиливи, що виникають спонтанно чи внаслідок травм, а ступінь їх тяжкості корелює зі ступенем тяжкості самого захворювання. При цьому тяжкість її перебігу напряму залежить від ступеня недостатності коагуляційної активності фактора згортання крові. У нормі концентрація FVIII і FIX в крові незначна та становить 1-2 мг і 0,3-0,4 мг на 100 мл (або 1 молекула FVIII на 1 млн молекул альбуміну), але при дефіциті одного з факторів порушується процес згортання крові в першу його фазу (утворення тромбопластину) по внутрішньому шляху активації, що зумовлює відстрочений гематомний тип кровоточивості. На сучасному етапі залежно від ступеня зниження концентрації антигемофільного глобуліну в плазмі крові, гемофілію прийнято класифікувати на три форми: легку, середньої тяжкості та тяжку (табл. 2). 
Таблиця 2 Ступені тяжкості гемофілії залежно від активності фактора згортання крові

\begin{tabular}{lcc}
\hline & \multicolumn{2}{c}{ Класифікація гемофілії за ступенем тяжкості } \\
\hline & Ступінь тяжкості & Активність фактора,\% \\
\hline Тяжкий & $<1$ \\
\hline Середньотяжкий & $1-5$ \\
\hline Легкий & $5-50$
\end{tabular}

Нормальним вважають рівень активності фактора згортання крові 50-150\%. Залежно від активності фактора згортання у пацієнтів превалює специфічна клінічна картина. Так, при легкій формі хвороби сильні кровотечі виникають в разі серйозних травм або великих хірургічних втручань. Гемофілія середньої тяжкості характеризується сильними кровотечами при травмах, хірургічних втручаннях, також можливі спонтанні кровотечі. При тяжкій формі гемофілії прояви захворювання відзначають із раннього віку (з перших днів/місяців життя), характерна наявність тяжкого геморагічного синдрому. У структурі геморагічних проявів при гемофілії одним із провідних симптомів $\epsilon$ крововилив у суглоби — гемартроз - одне 3 найнебезпечніших ускладнень, який в іноземній літературі часто описують як спричинене кров'ю захворювання суглоба (blood induced joint disease) [13]. Особливості гемартрозу у пацієнтів із гемофілією:

- уражаються великі суглоби (колінні, ліктьові, плечові, гомілковостопні);

- частіше відмічають у дітей старшого віку (оскільки вони більше рухаються);

- можливий спонтанний крововилив у суглоб;

- наявність місцевої симптоматики: збільшення суглоба, почервоніння, локальне підвищення температури тіла;

- набряк, обмеження рухливості, біль при русі;

- тенденція до прогресування патології з розвитком артриту, анкілозу, що стає причиною інвалідизації пацієнта.

Внаслідок труднощів у контролі епізодів кровотеч у пацієнтів з інгібіторами наявний підвищений ризик розвитку тяжких кровотеч. На відміну від ІФГ, при якій відмічають крововилив в м'язи та суглоби, для пацієнтів з НГА більш характерною $\epsilon$ поява спонтанних великих гематом, тяжкої гематурії, ретрофарингеальних і ретроперитонеальних гематом та крововиливів в головний мозок. Кровотечі часто бувають масивними, небезпечними для життя.

Відповідно до даних літератури у пацієнтів з інгібіторами до факторів згортання крові відмічають:

- ризик прогресуючого захворювання суглобів, що призводить до інвалідності;

- ризик погіршення якості життя, зумовленого станом здоров'я;

- потребу в пристроях, що полегшують мобільність, та ортопедичній хірургії.

Патологічні процеси, зокрема гіпертрофія синовіальної оболонки, ії гіперваскуляризація та дегенерація хряща, які виникають внаслідок крововиливу в суглоб, у подальшому призводять до специфічного ураження суглобів - гемофілічної артропатії, яка $\epsilon$ основною причиною інвалідизації дітей ще до досягнення повноліття, а в деяких випадках - і в дошкільному віці. Результати дослідження М.B. Funk та співавторів (2002), в якому брали участь 15 пацієнтів із гемофілією, продемонстрували, що кількість суглобових кровотеч напряму пов'язана з ураженням суглобів. Так, 3-4 гемартрози на рік значно погіршують якість життя дітей з гемофілією та можуть спричинити ранню інвалідизацію. При цьому якість життя пацієнтів із гемофілією, що не мають жодної кровотечі протягом року, практично відповідає такій у пацієнтів без гемофілії [14]. Результати іншого дослідження, в якому оцінювали функціональну спроможність кінцівок у пацієнтів із гемофілічною артропатією, продемонстрували, що гемартрози асоційовані з наявністю у хворих відносного укорочення верхніх та нижніх кінцівок, дефіциту об'єму рухів у ліктьових суглобах на $36 \%$, колінних - 38\%, гомілковостопних - $10 \%$, що суттєво обмежує самообслуговування, зумовлює швидке виснаження під час фізичного навантаження та значно погіршує якість життя пацієнтів [15].

\section{НГА: діагностика та диференційна діагностика $з$ іншими порушеннями гемостазу}

Якщо ключовими симптомами при класичній гемофілії, які вказують про розвиток інгібітора до фактора згортання крові, $\epsilon$ наявність безконтрольних кровотеч та відсутність відповіді на введення звичайної дози концентратів факторів згортання, то діагноз НГА може бути запідозрений у пацієнтів із аномальною кровотечею чи подовженим активованим частковим протромбіновим часом (АЧТЧ) за умови відсутності особистого/сімейного анамнезу розладів згортання крові. Так, розвиток ІФГ зазвичай діагностується, коли хворий або члени його сім'ї помічають, що гемостатична терапія стає менш ефективною, ніж зазвичай, або кровотеча не зупиняється у визначені терміни на тлі адекватного лікування. При менеджменті пацієнтів із НГА діагностика $є$ більш складною, оскільки сама по собі набута гемофілія $\epsilon$ складним клінічним випадком, і недостатня обізнаність медичного персоналу може призвести до затримки діагностики та/або неадекватного лікування, що в майбутньому призведе до захворюваності та високої смертності пацієнтів. Відповідно до сучасних рекомендацій, діагноз НГА рекомендовано розглянути у пацієнтів із симптомами аномальної кровотечі, яка супроводжується подовженням АЧТЧ (рис. 3). Важливо враховувати, що до подовження АЧТЧ також можуть призводити наявність інгібітора до факторів згортання крові, екзогенний прийом антикоагулянтів або ізольований дефіцит FVIII, FIX, FXI i FXII [16].

\section{Рисунок 3 Діагностика НГА [17]}

Попередній анамнез кровотеч (виключити спадкові та медикаментозні причини) $\downarrow$

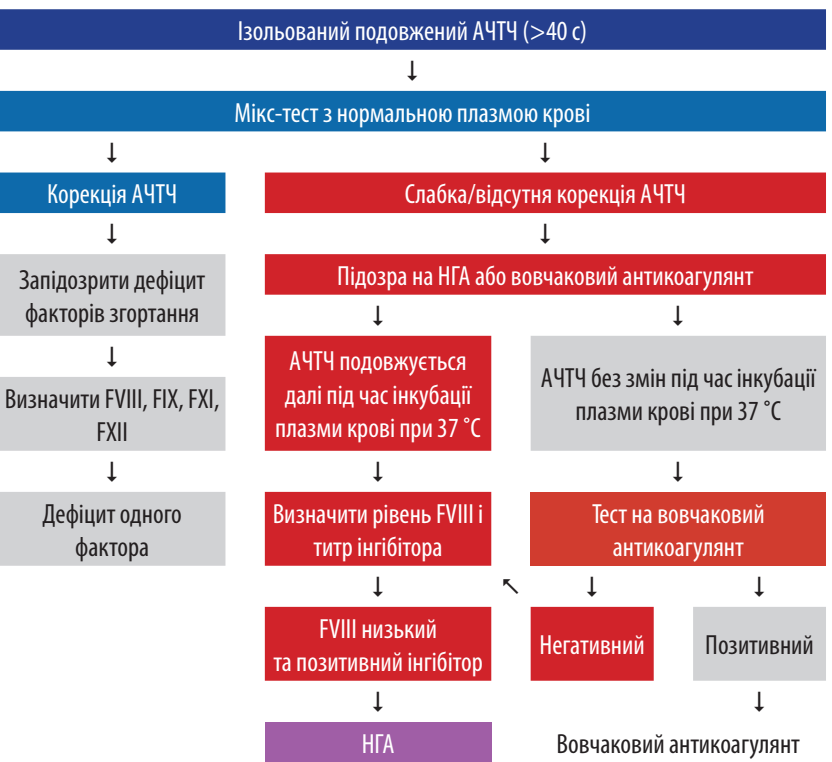

Найбільш простим способом диференційної діагностики між наявністю інгібітора до факторів згортання крові та ізольованим дефіцитом факторів згортання $\epsilon$ проведення так званого мікс-тесту, або тесту змішування, суть якого полягає у змішуванні плазми крові пацієнта з нормальною плазмою у співвідношенні 1:1 і подальшою повторною оцінкою АЧТЧ (рис. 4). У разі відсутності в крові хворого інгібітора відбувається корекція показника АЧТЧ до нормальних значень, якщо ж інгібітор наявний, то корекції АЧТЧ не відбувається. Оскільки інгібітор за своєю суттю $€$ «повільним» антитілом, інгібування фактора в звичайних умовах не може відбуватися негайно, в зв'язку з чим оцінку АЧТЧ проводять безпосередньо відразу і через 2 год після змішування. 
Рисунок 4 Мікс-тест

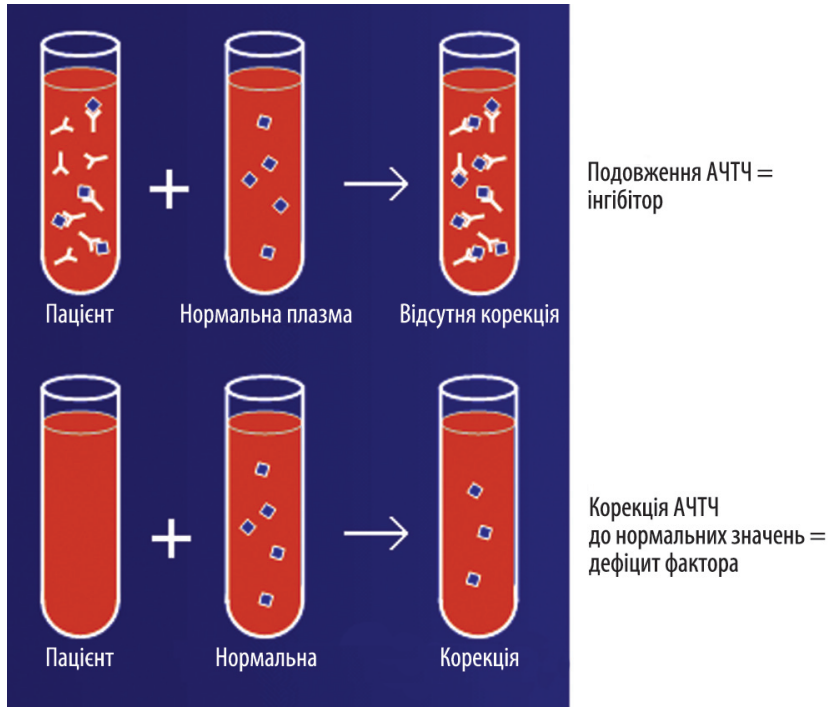

При позитивному результаті мікс-тесту з метою остаточного підтвердження діагнозу НГА проводиться визначення титру інгібітора методом Бетезда. Цей метод базується на здатності інгібітора інактивувати FVIII. Розведену плазму, яка містить інгібітор, протягом 2 год інкубують в суміші 3 плазмою, яка має нормальну активність FVIII, при температурі $37^{\circ} \mathrm{C}$, далі вимірюють залишкову активність FVIII в БО. Крім методу Бетезда існує імуноферментний метод (ELISA), що ґрунтується на специфічній реакції антиген-антитіло, при якому молекули FVIII адсорбовані на твердій фазі, однак значного поширення в клінічній практиці він не отримав, оскільки дозволяє визначати лише наявність або відсутність антитіл, не уявляючи інформації про їх інгібіторну активність.

Відповідно до сучасних рекомендацій діагноз НГА рекомендовано встановлювати з урахуванням типової клінічної картини (аномальна кровотеча без особистого/сімейного анамнезу розладів згортання крові), а також результатів клінічних досліджень (подовжений АЧТЧ). Диференційну діагностику НГА рекомендовано проводити із захворюваннями, які мають схожу клінічну картину, та результатами лабораторних досліджень [18]. Зокрема, схожі дані можуть відмічати при гемофілії А та В, спадкових дефіцитах факторів згортання крові та інших станах, що супроводжуються патологією гемостазу (печінкова недостатність, дефіцит вітаміну К, ефект гепарину, порушення функції тромбоцитів та ін.) [19].

\section{Принципи лікування набутої гемофілії на сучасному етапі}

Адекватна фармакологічна терапія залежить в першу чергу від наявних фонових захворювань, які зумовлюють її розвиток і клінічну маніфестацію коагулопатії. При менеджменті пацієнтів із НГА важливо дотримуватися ключових принципів лікування:

- лікування слід проводити за консультацією фахівців з гемофілії та в центрі, який має досвід менеджменту пацієнтів із НГА;

- пацієнти не повинні піддаватися інвазивним процедурам, в яких немає істотної необхідності;

- рішення щодо імуносупресії слід приймати негайно, щоб мінімізувати час ризику кровотеч;

- затримка в лікуванні може призвести до зайвого підвищення ризику тяжких кровотеч.

Фундаментальними аспектами терапевтичної тактики менеджменту хворих з НГА $є$ зупинка кровотеч, ерадикація інгібітора та лікування супутніх захворювань та станів (рис. 5). Відповідно до сучасних рекомендацій, стратегії зупинки кровотеч у хворих з НГА представлені:

- терапія 1-ї лінії - застосування шунтуючих препаратів:

- антиінгібіторний коагуляційний комплекс (аРСC).
- рекомбінантний активований FVII (rFVIIa).

- рекомбінантний свинячий FVIII;

- при недоступності/непереносимості шунтуючих препаратів:

- людський FVIII;

- десмопресин;

- при неефективності 1-ї лінії терапії:

- плазмаферез та/або екстракорпоральна імуносорбція.

Рисунок 5 Алгоритм лікування НГА

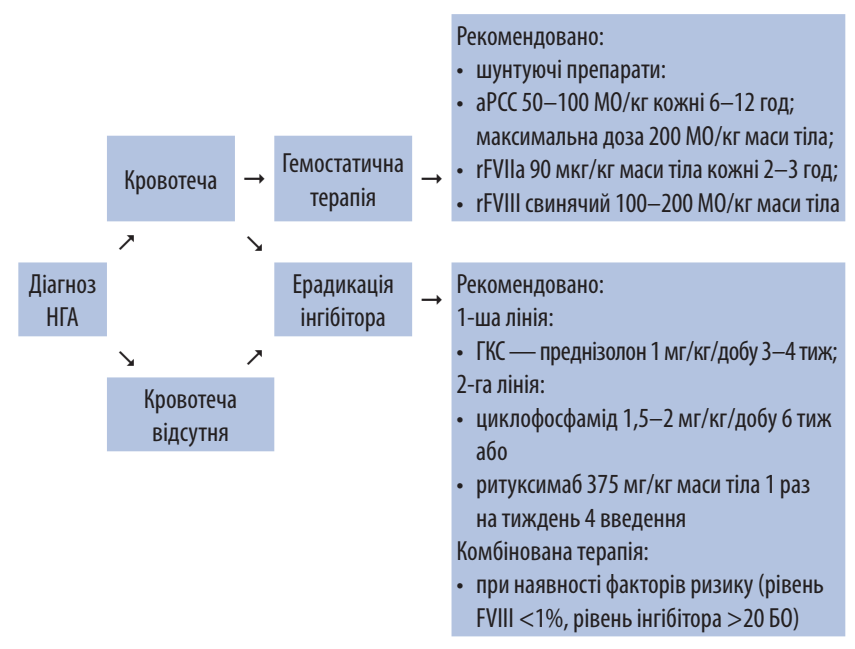

ГКС - глюкокортикостероїди.

Для ерадикації інгібітора до факторів згортання крові показана імуносупресивна терапія із застосуванням ГКС. Сучасні рекомендації регламентують проведення імуносупресивної терапії одразу ж після підтвердження діагнозу НГА, оскільки до моменту ерадикації інгібітора у пацієнта відмічають ризик кровотеч, включно $з$ фатальними [20]. Найчастіше як 1-шу лінію терапії для ерадикації інгібітора до факторів згортання крові застосовують ГКС або комбіновану терапію із застосуванням ГКС разом з цитостатиком, через їі високу ефективність (60-80\%). Імуносупресивна терапія 2-ї лінії показана, якщо рівень FVIII не почне підвищуватися, а титр інгібітора знижуватиметься після 2-3 тиж після застосування 1-ї лінії, та включає застосування ритуксимабу (альтернативні препарати представлені азатіоприном, вінкристином, циклоспорином та ін.).

Таким чином, гемофілія $\epsilon$ тяжким і небезпечним для життя розладом системи згортання крові, який характеризується розвитком тяжких, часто фатальних кровотеч. Відповідно, інформування клініцистів про це захворювання може допомогти уникнути затримки у діагностиці та призначенні адекватного лікування. Враховуючи той факт, що клінічна картина дебюту захворювання, тяжкість перебігу, активність інгібітора та ефективність гемостатичної терапії є індивідуальними для кожного пацієнта, доцільним $\epsilon$ наведення власного досвіду менеджменту пацієнтів із інгібіторами до факторів згортання крові.

\section{Клінічний випадок № 1}

Хлопчик, 11 років. Діагноз: гемофілія А тяжкого ступеня, інгібіторна форма з високим титром антитіл та сильною імунною відповіддю.

Анамнез хвороби: зі слів матері з 7-місячного віку у хлопчика почали з'являтися спонтанні гематоми, які повільно розсмоктувалися без лікування впродовж 2-3 тиж. Вперше на консультацію до гематолога звернулися у віці дитини 9 міс зі скаргами на блідість та наявність обширних гематом на передній поверхні грудної клітки та в ділянці чола.

Анамнез життя: дитина від VI доношеної вагітності, IV фізіологічних пологів.

Спадковий анамнез: дід по материнській лінії хворів на гемофілію А, троє старших рідних братів здорові, двоє рідних молодших братів (віком 2 і 9 років) хворіють на тяжку форму гемофілії $\mathrm{A}$ та отримують профілактичне лікування FVIII, інгібіторні антитіла у них відсутні. 
Діагноз гемофілії А вперше встановлений у віці 9 міс, підтверджений дослідженням коагулограми з кількісним визначенням FVIII, який становив 0,18\%, інгібіторні антитіла до FVIII відсутні. Тоді ж діагностована хронічна постгеморагічна залізодефіцитна анемія середньої тяжкості.

3 огляду на частоту та тяжкість геморагічних проявів гемофілії у віці 10 міс дитині було розпочато профілактичне лікування рекомбінантним фактором коагуляції людини VIII (октоког альфа) в режимі імунної толерантності ( $25 \mathrm{MO} /$ кг маси тіла внутрішньовенно струминно один раз на тиждень), яке пацієнт переносив добре. Геморагічні ускладнення гемофілії на фоні цього лікування були мінімальними (короткочасна кровотеча з ясен, дрібні екхімози м'яких тканин тулуба та кінцівок). Планове визначення інгібіторних антитіл до FVIII після проведення перших 10 ін'єкцій октокогу альфа виявило їх у високому титрі (18,9 БО/мл), після чого терапія FVIII була припинена.

У даній клінічній ситуації доцільним було провести лікування, спрямоване на ерадикацію інгібіторних антитіл, а саме: терапію індукції імунної толерантності. Проте з огляду на вкрай обмежене забезпечення факторами коагуляції з державних закупівель та їх особливо високу вартість цей вид лікування на той час виявився недоступним, як і профілактичний режим лікування антиінгібіторним комплексом чи фактором VIla. Тому хлопчик був переведений на замісну гемостатичну терапію антиінгібіторним коагуляційним комплексом в дозі 100 МО/кг маси тіла на одне введення в режимі «на вимогу», тобто при появі геморагічних ускладнень гемофілії. Впродовж наступних 12 міс у дитини виявлено 4 епізоди геморагічних ускладнень гемофілії (гематоми м'яких тканин сідниць, грудної клітки та калитки), які потребували замісної гемостатичної терапії антиінгібіторним комплексом.

Через 16 міс після припинення терапії FVIII титр інгібіторних антитіл у дитини знизився до 0,5 БО/мл.

При спробі відновити хлопчику терапію FVIII після одноразової його ін'єкції в дозі $50 \mathrm{MO} / к г$ маси тіла на 7-му добу титр інгібіторних антитіл зріс до 122 БО/мл. Від того часу пацієнт жодного разу не отримував терапію FVIII. Титр інгібіторних антитіл у пацієнта в подальшому знизився та коливається в межах 5,2-2,0 БО/мл.

Перший гемартроз (правий гомілковостопний суглоб) у хлопчика діагностовано у віці 7 років, у подальшому цей суглоб став так званим суглобом-мішенню, крововиливи у який відбувалися з частотою 2-3 рази на рік.

3 8-річного віку хлопчик отримував лікування антиінгібіторним коагуляційним комплексом у профілактичному режимі з частотою двічі на тиждень, яке тривало впродовж 3,5 року. Під час профілактичного лікування антиінгібіторним комплексом тяжких кровотеч чи спонтанних гемартрозів у дитини не виявлено.

Зараз пацієнт продовжує отримувати профілактичну терапію з приводу інгібіторної форми гемофілії відповідно до сучасних стандартів.

\section{Клінічний випадок № 2}

Пацієнтка Л., 35 років. Звернулася у листопаді 2017 р. до відділення екстреної медичної допомоги зі скаргами на виникнення спонтанних гематом на тілі.

При обстеженні виявлено наступне. Стан пацієнтки середньої тяжкості. Шкіра та слизові оболонки блідо-рожеві. На верхніх і нижніх кінцівках численні крововиливи за гематомним типом, зливного характеру, різного ступеня зрілості. Гемодинаміка стабільна. 3 анамнезу відомо: самостійні перші пологи 25.09.2017 р., вагітність перша, перебіг вагітності та пологів без особливостей. У ранній післяпологовий період спостерігалася маткова кровотеча. Отримувала свіжозаморожену плазму, транексамову кислоту, амінокапронову кислоту, фактор VIIa. На початку жовтня 2017 р. перенесла респіраторну інфекцію, після якої почали з'являтися спонтанні гематоми.

Дані додаткових методів обстеження від 17.11.2017 р.: гемоглобін 69 г/л, еритроцити 2,39.1012/л, лейкоцити 8,5·10\%/л, тромбоцити $468 \cdot 10^{\%} / л$, паличкоядерні нейтрофіли $6 \%$, сегментоядерні нейтрофіли $60 \%$, лімфоцити 17\%, моноцити 5\%, еозинофіли $10 \%$, метамієлоцити 1\%, базофіли 1\%. Коагулограма: міжнародне нормалізоване відношення (МНB) - 1,09 (норма 0,8-1,1), протромбін за Квіком 88,2\% (80-120\%), фібриноген плазми 5,1 г/л (норма 2,0-4,0 г/л), АЧТЧ - 122 с (норма 26,6-36,0 с). Біохімічний аналіз крові та клінічний аналіз сечі без особливостей. Комп'ютерна томографія органів грудної і черевної порожнини, малого таза патології не виявила. Взято аналіз на визначення рівня факторів коагуляції крові.

Встановлено діагноз: набута коагулопатія неуточненого генезу. За життєвих показань проведено лікування свіжозамороженою плазмою, кріопреципітатом, препаратами заліза.

Після проведеного лікування коагулограма мала наступний вигляд: МНВ - 1,01, протромбін за Квіком 98,5\%, фібриноген плазми 4,7 г/л, АЧТЧ - 52,3 с.

Призначене лікування кортикостероїдами (1 мг/кг/добу) не подіяло. Прийом азатіоприну 1,5 мг/кг/добу також не виявив ефекту.

Отримано результати визначення рівня фактору коагуляції крові VIII - 0,2\%. Коагулограма від 06.12.2017 р.: МHB - 1,11, протромбін за Квіком 88,6\%, фібриноген плазми 2,42 г/л, АЧТЧ — $109,8 \mathrm{c}$.

Враховуючи дані анамнезу, жіночу стать пацієнтки, особливості перебігу захворювання та отримані дані додаткових методів обстеження запідозрено наявність набутої гемофілії. Пацієнтка виписана зі стаціонару у відносно задовільному стані, ознак продовження кровотеч не відзначалося.

Подальше обстеження пацієнтка проходила у м. Мінськ. При обстеженні від 15.01.2018 р. виявлено наступне. Маркери аутоімунних захворювань негативні, коагулограма від 15.01.2018 р.: МHB - 1,01, протромбін за Квіком 108\%, АЧТЧ - 84,1 с, фактор VIII - 0\% (норма 50-100\%), інгібітор VIII - 376,32 БО/мл, фактор IX - 44\% (норма 50-100\%), інгібітор IX - 0,45 БО/мл, фактор XI - 35\% (норма 50-100\%), фактор XII - 40\% (норма 50-100\%). Клінічний аналіз крові: гемоглобін 114 г/л, еритроцити 3,7·1012/л, ретикулоцити 5,31\%, гематокрит 35,5\%, лейкоцити 8,13.10\%, тромбоцити 394.10\%/л, паличкоядерні нейтрофіли 7\%, сегментоядерні нейтрофіли $62 \%$, лімфоцити $17 \%$, моноцити 5\%, метамієлоцити $1 \%$, еозинофіли $10 \%$, базофіли $1 \%$.

На підставі проведеного обстеження встановлено діагноз: набута інгібіторна (інгібітор до фактора VIII - 376,32 БО/мл) гемофілія A, тяжка форма (рівень фактора VIII - 0\%). Залізодефіцитна анемія середнього ступеня тяжкості. Рекомендовано: у разі виникнення кровотеч, що загрожують життю, - введення з гемостатичною метою препаратів шунтуючого типу дії (фактор Vlla, антиінгібіторний коагуляційний комплекс); розглянути питання введення ритуксимабу 375 мг/м² внутрішньовенно 1 раз на тиждень, всього 4 введення; за відсутності можливості проведення терапії ритуксимабом - проведення курсу лікування імуноглобуліном внутрішньовенно у дозі 0,4 мг/кг маси тіла, вводити 5 днів поспіль; контроль рівня фактора VIII та інгібітора 1 раз на місяць.

3 01.02.2018 по 22.02.2018 р. пацієнтці проведено 4 введення ритуксимабу у дозі 375 мг/м² внутрішньовенно.

При контрольному обстеженні встановлено: коагулограма від 19.02.2018 р.: МНВ - 0,92, протромбін за Квіком 113\%, АЧтЧ - 89,8 с, фібриноген 4,24 г/л, фактор VIII - 0\%, інгібітор VIII - 243,2 БО/мл (зниження рівня лише на 35,4\% від базового рівня). Рекомендовано: у разі виникнення кровотеч, що загрожують життю, - введення з гемостатичною метою препаратів шунтуючого типу дії (фактор VIla, антиінгібіторний коагуляційний комплекс); розглянути питання щодо проведення курсу лікування імуноглобуліном внутрішньовенно у дозі 0,4 мг/кг маси тіла протягом 5 днів поспіль або 1,0 г/кг маси тіла 2 дні; контроль рівня фактора VIII та інгібітора 1 раз на місяць.

У період з 14.03.2018 по 26.03.2018 р. пацієнтка знову проходила лікування в умовах відділення невідкладної медичної допомоги з приводу сечокам'яної хвороби, ниркової коліки, макрогематурії на тлі набутої інгібіторної гемофілії А. При госпіталізації гемоглобін 115 г/л, еритроцити 3,85·10²/л, гематокрит 0,34, лейко- 
цити 8,5·10\%/л, тромбоцити 333.10\%/л, паличкоядерні нейтрофіли $8 \%$, сегментоядерні нейтрофіли $74 \%$, лімфоцити $10 \%$, моноцити 7\%, метамієлоцити 1\%. Коагулограма: МНB - 1,11, протромбін за Квіком 86,3\%, фібриноген плазми 4,9 г/л, АЧТЧ - 115,1 с.

Проведено лікування: свіжозаморожена плазма, спазмолітична, гемостатична, антибактеріальна, симптоматична терапія, імуноглобулін внутрішньовенно у дозі 0,4 мг/кг маси тіла 5 днів.

На момент виписки зі стаціонару: гемоглобін 81 г/л, еритроцити $2,78 \cdot 10^{12} / л$, гематокрит 0,25 , лейкоцити $6,9 \cdot 10^{9} / л$, тромбоцити $462 \cdot 10 \%$ л, паличкоядерні нейтрофіли $5 \%$, сегментоядерні нейтрофіли 76\%, лімфоцити 15\%, моноцити 3\%, метамієлоцити $1 \%$, еозинофіли $1 \%$. Коагулограма: МHB - 1,12, протромбін за Квіком 85,5\%, фібриноген плазми 4,9 г/л, АЧТЧ - 105,8 с.

Стан хворої залишався стабільним протягом наступного року, ознак кровотеч не виникало. При обстеженні від 24.01.2019 р.: рівень фактора VIII - 64,8\%, визначення рівня інгібітора не проводили; гемоглобін 136 г/л, еритроцити 4,58.1012/л, гематокрит 0,25 , лейкоцити $5,19 \cdot 10^{9} /$, тромбоцити $196 \cdot 10^{9} / л$, паличкоядерні нейтрофіли $2 \%$, сегментоядерні нейтрофіли $62 \%$, лімфоцити $27 \%$, моноцити 9\%. Коагулограма: МНВ - 1,03, протромбін за Квіком 100\%, фібриноген плазми 3,5 г/л, АЧТЧ - 32,07 с.

У період з січня 2019 по жовтень 2021 р. за медичною допомогою до гематологів пацієнтка не зверталася.

Аналіз наведеного клінічного випадку демонструє певні проблеми та невирішені питання у діагностиці, лікуванні та спостереженні пацієнтів із набутою формою гемофілії. Низький рівень обізнаності лікуючих лікарів з питань гемостазіології, несвоєчасне звернення за консультацією гематолога, відсутність доступу до сертифікованих лабораторій, що мають здатність проводити визначення рівня факторів коагуляції крові та інгібіторів до них, висока вартість лікарських засобів для лікування пацієнтів із набутою гемофілією призводять до несвоєчасної діагностики та неадекватної терапії.

За підтримки ТОВ «Такеда Україна» VV-MEDMAT-55276

\section{Список використаної літератури}

1. Стасишин 0.В. (2020) Спадкові порушення в системі гемостазу: фокус на сучасні можливості діагностики. Укр. мед. часопис, 6(1)(140). www.umj.com.ua/article/195042.

2. Knoebl P., Marco P., Baudo F. et al. (2012) Demographic and clinical data in acquired hemophilia A: results from the European Acquired Haemophilia Registry (EACH2). J. Thromb. Haemost., 10(4): 622-631. doi: 10.1111/j.1538-7836.2012.04654.x.

3. Ewenstein B.M., Putnam K.G., Bohn R.L. (2002) Nonhemophilic inhibitors of coagulation. In: Kitchens CS, Alving BM, Kessler CM, editors. Consultative hemostasis and thrombosis. Philadelphia, PA:WB Saunders, p. 75-90.

4. Huth-Kühne A., Baudo F., Collins P. et al. (2009) International recommendations on the diagnosis and treatment of patients with acquired haemophilia. Haematologica, 94(4):566-575.

5. Barlamov P.N., Shchekotov V.V.1, Shutylev A.A. et al. (2015) Postpartum acquired hemophilia. Klin. Med., 93(10): 67-71. (in Rus.).

6. Khair K., Chalmers E., Flannery T. et al. (2021) Expert opinion on the UK standard of care for haemophilia patients with inhibitors: a modified Delphi consensus study. Ther. Adv. Hematol., 12: 20406207211007058.r 30. делфи

7. Ljung R., Auerswald G., Benson G. et al. (2019) Inhibitors in haemophilia A and B: Management of bleeds, inhibitor eradication and strategies for difficult-to-treat patients. Eur. J. Haematol. 102(2): 111-122. doi:10.1111/ejh. 13193.

\section{Відомості про авторів:}

Цимбалюк-Волошин Ірина Петрівна — лікар гематолог дитячий вищої категорії, кандидат медичних наук, завідувач відділення гематології та інтенсивної хіміотерапії, Західноукраїнський спеціалізований дитячий медичний центр, Львів, Україна.

Кучкова Ольга Юріївна — лікар-гематолог гематологічного відділення, Обласний центр онкології, Харків, Україна.

\section{Адреса для кореспонденції:}

Цимбалюк-Волошин Ірина Петрівна

79035, Львів, вул. Дністерська, 27
8. Tieu P., Chan A., Matino D. (2020) Molecular Mechanisms of Inhibitor Development in Hemophilia. Mediterr. J. Hematol. Infect. Dis., 12(1): e2020001. doi:10.4084/MJHID.2020.001

9. Третьякова 0.С. (2012) Гемофилия у детей: этиопатогенез, клинические проявления, диагностические подходы. Дит. Лік., 3-4 (16-17): 26-35.

10. Sakurai Y., Takeda T. (2014) Acquired hemophilia A: a frequently overlooked autoimmune hemorrhagic disorder. J. Immunol. Res., 2014: 320674. doi: 10.1155/2014/320674.

11. Kreuz W., Gill J.C., Rothschild C. et al. (2005) Full-length sucrose-formulated recombinant factor VIII for treatment of previously untreated or minimally treated young children with severe haemophilia A: results of an international clinical investigation. Thromb. Haemost., 93(3): 457-467. doi: 10.1160/TH03-10-0643.

12. Dimichele D., Négrier C. (2006) A retrospective postlicensure survey of FEIBA efficacy and safety. Haemophilia, 12(4): 352-362.

13. Wessel L.M., Scholz S., Rüsch M. (2001) Characteristic pattern and management of intraarticular knee lesions in different pediatric age groups. J. Pediatr. Orthop., 21(1): 14-19. doi: 10.1097/00004694-200101000-00005.

14. Funk M.B., Schmidt H., Becker S. et al. (2002) Modified magnetic resonance imaging score compared with orthopaedic and radiological scores for the evaluation of haemophilic arthropathy. Haemophilia, 8(2): 98-103. doi: 10.1046/j.1365-2516.2002.00585.x.

15. Averyanov E.V. (2015) Changes in the functional capacity of the extremities in patients with hemophilia with posthemorrhagic arthropathy. Hematology and blood transfusion: Collection of scientific works, 38: 345-346. (in Ukr.).

16. Хиць А. (2020) Сучасні підходи до лікування пацієнтів з гемофілією: фокус на інгібіторну форму. Укр. мед. часопис, 5(139). www.umj.com.ua/article/189488.

17. Collins, P., Baudo, F., Huth-Kühne A. et al. (2010) Consensus recommendations for the diagnosis and treatment of acquired hemophilia A. BMC Res. Notes, 3: 161. doi.org/10.1186/17560500-3-161.

18. Yousphi A.S., Bakhtiar A., Cheema M.A. et al. (2019) Acquired Hemophilia A: A Rare but Potentially Fatal Bleeding Disorder. Cureus, 11(8): e5442. doi:10.7759/cureus.5442.

19. Shander A., Walsh C.E., Cromwell C. (2011) Acquired hemophilia: a rare but life-threatening potential cause of bleeding in the intensive care unit. Intens. Care Med., 37(8): 1240-1249. doi: 10.1007/s00134-011-2258-5.

20. Franchini M., Mannucci P.M. (2013) Acquired haemophilia A: a 2013 update. Thromb. Haemost., 110(6): 1114-1120. doi: 10.1160/TH13-05-0363.

\section{Acquired hemophilia A: current approaches to treatment and clinical cases}

\section{I.P. Tsymbalyuk-Voloshin', O.Yu. Kuchkova ${ }^{2}$}

${ }^{1}$ Western Ukrainian Specialized Children's Medical Centre, Lviv, Ukraine ${ }^{2}$ Regional Center of Oncology, Kharkiv, Ukraine

Abstract. Classical hemophilia is an X-linked disease of the hemostasis system characterized by decreased or impaired synthesis of coagulation factors. Most doctors believe that hemophilia is a hereditary pathology, but in clinical practice, in addition to the hereditary form, there is acquired hemophilia, which is an extremely rare pathology, based on the production of autoantibodies that inactivate coagulation factors. The article presents a literature review on key aspects of the management of patients with hemophilia, focusing on the problem of acquired hemophilia $A$, as well as our own clinical observations of successful treatment of patients with inhibitors to coagulation factors.

Key words: hemophilia, hemostasiopathy, hemostasis, acquired hemophilia A, shunt drugs, blood coagulation factor, hemarthrosis.

\section{Information about the authors:}

Tsymbalyuk-Voloshin Iryna P. — Pediatric hematologist of the highest category, Candidate of Medical Sciences, Head of the Hematology department, Western Ukrainian Specialized Children's Medical Centre, Lviv, Ukraine.

Kuchkova Olga Yu. - Hematologist of Hematology department, Regional Center of Oncology, Kharkiv, Ukraine.

Address for correspondence:

Iryna Tsymbalyuk-Voloshin

79035, Lviv, Dnisterska Str., 27 